\title{
Teachers' Perception about Authentic Materials and Their Implementation in the Classroom
}

\author{
Khoirul Anam, khoirulanam@gmail.com, UNESA, Surabaya, Indonesia \\ Ahmad Munir, ahmadmunir@ unesa.ac.id, UNESA, Surabaya, Indonesia \\ Syafiul Anam, syafiulanam@unesa.ac.id, UNESA, Surabaya, Indonesia
}

\begin{abstract}
Authentic materials are one of common materials in teaching English. Most of teacher usually use them to be implemented into their classroom. One of the reasons of the teachers they use it in the classroom is in order to give the students example of the real use of English in social life. Other than authentic materials, the teachers also usually use textbook. It is because textbook gives much easier for the teachers to use it in the classroom and also for the students to studied at home. In implementing the authentic materials is not as easy as using textbook. The teachers need to be creative to select and modify the authentic materials to be able to be implemented. It is because the authentic materials are not produced for pedagogical purposes. So, in this study, the objectives of the researcher are to seek about the perception of using authentic materials in the classroom, the reasons of the teachers about the perception, and also the way of the teachers when implementing the authentic materials in the classroom. Regarding the objectives above, the qualitative research is appropriate to be conducted in this study. It is in order to get the deep data from the research subject. To get the data, this study uses interview and observation. By the interview, it gets the answer of all the research questions. And by the observation, it gets the supporting data from the interview. For data analysis, this study uses Dornyei theory to analyze the data. It is started from transcribing the data, coding, growing ideas, interpreting the data, and drawing conclusion. The result of the research found that most of the teachers give positive response about using authentic materials in their teaching. They perceive that authentic materials are very important to be implemented in the classroom. The teachers also enjoy during the implementation of the authentic materials. They also perceive that authentic materials are very easy to get. And, the last perception is some of the authentic materials are very difficult for the students. For the conclusions, most of teachers are agree about the use of authentic materials for teaching English. Beyond the importance of the authentic materials the teachers only use several authentic materials that provide entertaining to the students like song and movies. The teachers rarely used kinds of authentic materials that contains text like newspaper, magazine and article in order to the difficulties of the words used in the text. Most of the teachers use kinds of authentic materials just to be supplementary materials other than using textbook materials.
\end{abstract}

Keywords: teachers' perception, authentic materials, implementation 


\section{INTRODUCTION}

Authentic materials are common materials used by many teachers in their teaching language. There are many reasons why an English teacher using them. Some researchers also have found that authentic materials have many benefits in teaching language process. Peacock (1997) said that authentic materials have a positive effect on students' motivation in learning foreign language. It is also quoted by Berardo (2006) from Widdowson that the language presented in the classroom should be authentic.

Authentic materials are common materials used by many teachers in their teaching language. There are many reasons why an English teacher using them. Some researchers also have found that authentic materials have many benefits in teaching language process. Peacock (1997) said that authentic materials have a positive effect on students' motivation in learning foreign language. It is also quoted by Berardo (2006) from Widdowson that the language presented in the classroom should be authentic materials. Like what has done by Mamo (2013), Rasheed (2014), Belaid (2015), Akbari and Razavi (2016), and Ahmed (2017), mostly they talked about the use of authentic materials. Mamo (2013) did a research on the use of authentic materials in teaching listening skills to college students. He found that such authentic materials on listening like song, etc. expose the students to the real world. Such teachers also awares to use authentic materials in listening skill. He suggested that students lavel, interest, relevance and quality of the materials should be appropriate to the authentic materials. It means that between authentic materials and the students need should be relevance (Mamo, 2013).

In addition to Mamo, the closely finding found by Akbari and Razavi (2016), they found that authentic materials are exposing the students to the real language and real society. They also found that most of the teachers believed that the language level of the text and the course objectives are the guiding ceriteria for selecting appropriate text. Other studies on authentic materials are also done by Rasheed (2014), Belaidi (2015) and Ahmed (2017). Rasheed (2014) found that the teachers believed that authentic materials could help the students practice English in real life. He also found that the students were motivated in learning English by using authentic materials. Moreover, Belaidi (2015) held a research on teacher's attitudes and prceptions on using authentic materials. He found that some EFL teachers emphasized on their regular use of authentic materials in their language classes.

Most of teachers also hold possitives attitude in using authentic materials. Meanwhile, Ahmed (2017) mentioned that some authentic materials used in classroom are devided into four parts. They are audio visual, paper, realia, and audio. Materials that are nclude to the audio visual are like movies, cartoon, serial dramas, sport, and interview. While the materials that include to the paper such as pictures, posters, photograph, calender, cue cards, newspaper, magazines, etc. Materials that include to the realia are restaurant menu, brocure, air ticket, wedding card, etc. While that include to the audio are news radio, interview, comentary, etc. (Ahmed, 2017).

In addition of those researchers, about the problems of the teachers in using authentic materials, Anam (2012) stated that the difficulties in authentic materials are a lot. For the example, the teachers have to prepare the authentic material as good as possible, they also have to filter the authentic materials so they are appropriate for learning process. Because the teachers have to prepare and filter the authentic materials as good as possible, the teachers need much time to do that.

Moreover, in the teaching process, the teacher also found several problems. The authentic materials like video or internet, the teachers need many tools to support their teaching process 
like LCD, electricity, and WIFI to connect to internet. The problems are when the school doesn't support those things the teaching process will be failed. And sometimes if there are some errors in internet connections or in electricity, the teaching process will surely be failed or changed with other materials (Anam: 2012).

From those findings of the studies, there is limited information about teachers' perceptions and the ways on using authentic materials. Hence, it is very interesting to know teachers' perceptions about using authentic materials, the reasons for holding such perspective, and the ways they have in using authentic materials. Rasheed (2014) in his research believed that authentic materials could help the students practice English in real life and the students were motivated in learning English. in addition, Belaidi (2015) found that some EFL teachers, emphasized on their regular use of authentic materials in their language classes. Most of teachers also hold possitives attitude in using authentic materials.

There are some advantages in using authentic materials for language teaching. Richard (2001) quoted from Philips, Shettlesworth, Clarke and Peacock stated that authentic materials have good effects to motivate the students. First, authentic materials give authentic cultural information about the target language. Second, they also provide exposure to real language and relate more closely to students' needs. The last, they can support a more creative approach to teaching. Tamo (2009) stated, "Authentic materials have a positive effect on learner motivation."

Moreover, there are several advantages in using authentic materials for teaching English. They are exposing to real discourse for the learner, informing the learner what is happening in the real world, producing a sense of achievement, able to be used under different circumstances, ideal to teach/practice skimming and scanning for reading texts, containing a wide variety of text types, able to encourage reading for pleasure because they contain interesting topics to the learners (Martinez, 2012).

From those ideas, it can be concluded that most of them agree that authentic materials are very useful in motivating students' learning. They also agree that authentic materials can stimulate students to study more about the language on their own way when the teacher have introduced the authentic materials during the teaching process.

However, there are also many disadvantages in using authentic materials for teaching English. Richard (2001) stated that authentic materials often contain difficult language and unneeded vocabulary items. They are also a burden for the teachers. own way when the teacher have introduced the authentic materials during the teaching process.

Using authentic materials is one of the big problems that many experts on language teaching have tried to implement it. In order to the advantages and the positive effect of authentic materials in developing student's skill on language, to implement the authentic materials is not as easy as using the coursebook. (Kilickaya, 2004) It is because there are also some problems that have found by some researchers when the teacher using them.

The disadvantages normally appear because the authenticity of the language itself. Therefore, they will disappear if the teachers anticipate the problems. They will also be reduced to the students' interest of language using. Tamo (2009) quoted from Chaves stated that the students still enjoy the language since they can interact with the real language in use. It seems that the learners need pedagogical support when learning with authentic materials.

Anam (2012) stated that the difficulties in using authentic materials are a lot. The difficulties or the problems appeared not only during teaching process, but they also appeared when they were preparing the authentic materials, during the process of teaching, and the way 
they were going to assess the students. In preparing authentic materials, the teachers have to prepare the authentic material as good as possible, they also have to filter the authentic materials so they are appropriate for learning process. Because the teachers have to prepare and filter the authentic materials as good as possible, the teachers need much time to do that.

Moreover, in the teaching process, the teacher also found several problems. The authentic materials like video or internet, the teachers need many tools to support their teaching process like LCD, electricity, and WIFI to connect to internet. The problems are when the school doesn't support those things the teaching process will be failed. And sometimes if there are some errors in internet connections or in electricity, the teaching process will surely be failed or changed with other materials (Anam, 2012).

In using authentic materials some teachers need to be creative in developing the lesson plan. It is because the authentic materials are taken from the real field of English itself. (Mishan, 2005) It is not taken from a coursebook. When the teachers are using authentic materials in the classroom, there are some aspects that they have to pay much attention such as when choosing the appropriate authentic materials, how to realize them into classroom, and how to evaluate them (Anam, 2012).

There are some strategies before choosing the authentic materials that have to be known by the teachers. The first is the goal of teaching. The teacher has to know firstly about the goal. What skill are they going to teach, such as speaking, reading, listening, or writing? What aspect that will be stressed, such as pronunciations, structure of the language, vocabulary, or etc.? The teacher should decide it in the first time so they do not get wrong in choosing which authentic materials are appropriate.

The teacher also can decide then what they are going to do with the authentic materials. One authentic material could be used in many aspects of English skills. Akbari and Razavi (2016) stated in their research that authentic materials are exposing the students to the real language and real society. So the teachers goal must be relevant with the authentic materials.

\section{METHOD}

This research is conducted by using a qualitative method. Specifically, it uses a descriptive qualitative research method. According to Nassaji (2015) descriptive qualitative research method is commonly used in researching language. He said that this method has been very common procedures for conducting research in many disciplines, including education, psychology, language, and social sciences. In that way, it is very good to conduct this research by qualitative method.

The characteristic of qualitative research method is naturalness of the data. It works with a wide range of data including recorded interview, various types of text, and images. (Dornyei, 2007) According to the objective of the study, this research needs to be as natural as possible to get the validity of the result of the study. This study also needs to be variety so the result can be reach. In that way, qualitative research method is very needed.

In this case, the teachers that were researched were the teachers in an Islamic Senior High School in Surabaya. In other word, the researcher in this study was done by myself. There were two teachers that became the subject in this study. The first teacher has already been teaching English there for about 8 years. The second teacher is still new teacher there. She has been teaching there for about 2 years. 


\section{RESULT}

Perception of teacher is needed when the teacher wants to decide what they are going to teach. Stated from Abbas (2017) from Zheng that teachers' perceptions are significant ideas in comprehending teachers' thought processes, teaching methods, and learning to teach. Moreover, he also stated that teacher perceptions are significant subjects in teacher education that have been designed to help teachers develop their thought and principles (Abbas Pourhosein Gilakjani, Narjes Banou Sabouri, 2017). So, the teacher perception here is the one thing that is need before they decide what materials that they use. The materials it can be text book material, authentic materials, or other teacher's own materials.

About the perception of the teacher on the materials that is authentic in teaching English is very important. Almost many teachers agreed that authentic materials are very important in developing their teaching strategy in the classroom. They are not only using textbook materials that sometimes are monotonous but they also add such authentic materials. Omid Akbari, Azam Razavi (2016) stated that Many empirical studies have demonstrated the positive effects of authentic materials taken by learners who have opportunities to interact and deal with them. They also added that the idea of using authentic material in language teaching is supported among references and many professionals in the field of language pedagogy (Omid Akbari, Azam Razavi, 2016). Those means that many experts of English and also the teachers or the professionals themselves agree the use of authentic materials are very needed and very important to be implemented in teaching English.

Even though, the teachers strongly agree that in teaching English they are not always use the authentic materials in every they are teaching English. Mostly they use the authentic materials to support their teaching strategies and teaching materials in order to make the students not to be bored. It is also because in the school they have to follow with the text book curriculum, so the authentic materials are only to be the supplementary materials in their teaching. In other that, the teachers also have little opportunities in implementing the authentic materials in the classroom. It is because their time to teach is not so many so they use the authentic materials outside of the class. it is to make the students learn by themselves at home and to be the assignment for the students at home.

Teaching materials are complex. There are at list 2 kinds of materials for teaching English. They are textbook and authentic materials. The teacher in senior high school mostly used textbook as the teaching materials. It is because they choose the easiness way to be implement into the classroom. In textbook, the teachers just follow the materials and the lesson plan, and the students also have already got the materials and studied at home. But, through authentic materials, the teachers will find some difficulties, like how to use it, what materials are going to teach, and also how to get the materials.

Especially for printed materials like newspaper, magazine and etc., firstly, the teachers get difficult to get. Very few printed newspapers are written in English and they also do not provide freely so rarely the teacher want to use it as the teaching materials. The same reasons are also about printed magazine. Most of schools and also the teachers do not have magazine written on English. They also do not want to spend much money just to buy a magazine. The second is because most of newspaper and magazine use the high language feature so they will make the students get difficulties to understand the text and get the lesson. When the authentic materials are not interesting to the students and they provide the difficulties, the student will even demotivated. 
The third reasons about the printed materials is they have already provided in the textbook, so the teachers do not need to provide the authentic one. Most of teachers are prefer to use textbook in order to teach news item text rather than providing the real newspaper to the students. Using textbook in teaching news item text is much easier for the teachers and the students. The students will easily to understand the text because the text has already edited or made based on the level of the students. If the teacher use text in a real newspaper, the students and also the teachers will get difficult to understand the text because of the language feature used in the newspaper. Moreover, the teachers will also need some money to buy the real newspaper to provide in the class, because they are not provided freely.

In implementing the authentic materials as stated above, surely the teachers have such reasons in their mind why they should use the authentic materials. Belaid (2015) stated that all of the teachers in his study prefer to use authentic materials in their language classes for different purposes. In addition, Shirin Nematollahi and Mojtaba Maghsoudi (2015) stated from Martinez that there are so many advantages of using authentic materials for teaching English. So, in this case, the teachers also have five reasons why they have to use authentic materials in their teaching.

In preparing the authentic materials is thinking about choosing the appropriate authentic materials. The teacher has to be able to analyze the student's ability, the students like, and the curriculum. It is in order to make the students get easy to understand and also to make the students enjoy during the lesson in the class. if the students do not get interest with the authentic materials or even it too difficult for the students, they will even be demotivated and bored in the class. Kilickaya (2004) believes that the use of authentic materials at lower levels causes students to feel frustrated and demotivated since students at these levels lack many lexical items and structures used in the target language. It means that the authentic materials chosen by the teacher should be appropriate based on, student's level ability, student's like, and appropriate to the curriculum.

Not only preparing the material and the media, the one thing that the teachers have to prepare is the activity during the class. because authentic materials are from the social life, the teacher have to make their own lesson plan first to make sure what they are going to do with the authentic materials. For the example, when the teacher using a song in the class, the teachers have to think what they are going to discuss with the song. The teacher can use the lyric of the song as the activity for the student in the class. And then, they can discuss whether the language function of the song or the content meaning of the song.

\section{CONCLUSION}

The authentic materials are very important to be implemented in the classroom as teaching materials. It is in order to make the students get motivated and interested to study English more and more. The authentic materials are very easy to get so the teachers should not be aware for the availability of them. They just need the internet and find the authentic materials they like from the internet.

In implementing the authentic materials, the teacher should prepare everything well before they come to the class. it is in order to get successful during the teaching process in the class. The teachers have to be more creative in choosing and selecting the authentic materials for the students. So, the students really get interest and motivated by the authentic materials. 


\section{REFERENCES}

Abbas Pourhosein Gilakjani, Narjes Banou Sabouri. (2017). Teachers’ Beliefs in English Language Teaching and Learning: A Review of the Literature.

Canadian Center of Science and Education, 78-86. Ahmed, S. (2017). Authentic ELT Materials in the Language Classroom: An Overview. Journal of Applied Linguistics and Language Research, 181-202.

Amirin, D. T. (1986). Menyusun Rencana Penelitian. Jakarta: Raja Grafindo Persada. Anam, K. (2012). Teachers' Difficulties in Using Authentic Materials For Teaching English in English Education Departement of Tarbiyah Faculty of IAIN Sunan Ampel, Surabaya. UIN Sunan Ampel.

Anjaniputra, A. G. (2013). Teacher's Strategies in Teaching Speaking to Students. Journal of English and Education, 1-8.

Ardila, F. (2015). An Analysis of Teachers' Perception on The Use of Authentic Reading Materials. PendidikanBahasa Inggris STKIP PGRI Sumatera Barat.

Arikunto, S. (2002). "Prosedur Penelitian Suatu Pendekatan Praktek" . Jakarta: Rineka Cipta. Belaid, A. M. (2015). Using Authentic Materials in the Foreign Language Classrooms: Teacher Attitudes and Perceptions in Libyan Universities. International Journal of Learning \&Development, 25-37.

Berardo, S. A. (2006). The Use of Authentic Materials in The Teaching of Reading. The Reading Matrix, 60-69.

Brenda Bowman, Grace Burkart, and Barbara Robson. (1989). TEFL/TESL: Teaching English as a foreign or second language. Washington: Peace Corps.

Brown, D. (2000). Principles of Language Learning and Teaching. England: Longman.

Buendgens, J. (2014). Authenticity. Key Concepts in ELT, 457-459.

Danim, P. D. (2002). Menjadi Peneliti Kualitatif. Bandung: Pustaka Setia.

Donald, A. (2002). Introduction to Research in Education. USA: Wadsworth Thomson Learning. Dornyei, Z. (2007). Research Methods In Applied Linguistics. new york. Dr. M.F. Patel and Praveen M. Jain. (2008). English Language Teaching (Methods, Tools \& Techniques). Jaipur: Sunrise Publishers \& Distributor.

Erik Jacobson, Sophie Degener, Victoria Purcell-Gates. (2003). Creating Authentic Materials and Activities for the Adult Literacy Classroom. Michigan: National Center for the Study of Adult Learning and Literacy (NCSALL).

Field, J. (2009). Listening in the Language Classroom. UK: Cambridge University Press.

Fitri, N. L. (2010). Teaching English By Using Authentic Material To Tenth Grade Students Of MAN Lamongan. English Education Departement of UIN Sunan Ampel.

Geoffrey Broughton, Christopher Brumfit, Roger Flavell, Peter Hill and Anita Pincas.

(2003).Teaching English as a Foreign Language. New York: Routledge.

Harmer, J. (1991). The Practice of English Language Teaching. England: Longman.

Kilickaya, F. (2004). Authentic Materials and Cultural Content in EFL Classrooms. The Internet TESL Journal.

Larenas, C. d. (2015). A Case Study on EFL Teachers' Beliefs About the Teaching and Learning of English in Public Education. Porta linguaruM 23, 171-186.

Mamo, K. (2013). The Use of Authentic Materials in Teaching Listening Skills to College

Students: The Cause of Bonga College of Teacher Education. 
Departement of Foreign Language and Literature, Addis Ababa University. Martinez. (2012, April 19). Authentic Materials: An Overview. Retrieved from Karen's Linguistics Issues: http://www.metu.edu.tr/ kilickay Martinez, A. (2002). Authentic materials: An overview. Free resources for teachers and students of English, Karen's Linguistics Issues, 1-7. Mishan, F. (2005). Designing Authenticity into Language Learning Materials. England: Intellect Books.

Mousavi, S. A. (2012). The Effect of Authentic Versus Non-authentic Aural Materials on EFL Learners' Listening Comprehension. English Language and Literature Studies, 21-27.

Nassaji, H. (2015). Qualitative and descriptive research: Data type versus data analysis. Language Teaching Research, 129-132.

Omid Akbari, Azam Razavi. (2016). Using Authentic Materials in The Foreign Language Classrooms: Teachers' Perspectives in EFL Classes. International Journal of Research Studies in Education, 105-116. Peacock, M. (1997). The Effect of Authentic Materials on the Motivation of EFL Learners. English Language Teaching Journal, 51.

PERMENDIKBUD. (2016). Standar Isi Pendidikan Dasar dan Menengah. Menteri Pendidikan dan Kebudayaan.

Pinsonneault, B. C. (2008). Authentic Input in Early Second Language Learning. University of Massachusetts - A mherst.

Rasheed, A. K. (2014). The Effect of Using Authentic Materials on The Spoken Use of English Verb Tenses For English as a Foreign Language Among Arab Secondary School Students in Malaysia. Doctor of Philosophy, University Utara Malaysia.

Rashid Hamed Al Azri, Majid Hilal Al-Rashdi. (2014). The Effect Of Using Authentic Materials In Teaching. International Journal of Scientific \& Technology Research, 249-254.

Richard, J. C. (2001). Curriculum Development in Language Teaching. Cambradge: Cambridge University Press.

Ryan, J. (2014). Authentic Materials in an EFL Curriculum : Appropriateness, Selection, Activity Design and promoting a Global Perspective. Shizuoka University of Art and Culture bulletin, 15-20.

Sample, M. G. (2015). Authentic Materials: A Motivational Tool For The EFL Classroom. Education \& Linguistic Research.

Sanz, L. L. (2014). English language teaching material. Publicaciones Didacticas, 19-21.

Sarjan, N. (2017). An Analysis on The English Teachers Strategies in Teaching Reading Comprehension at the Second Grade Students of Junior High School 1 of Wonomulyo. Alauddin State Islamic University of Makassar. Shirin Nematollahi, Mojtaba Maghsoudi. (2015). The Effect of Authentic Versus Non-Authentic Texts on Upper Intermediate Iranian EFL Learners' Vocabulary Retention. Canadian Center of Science and Education, 112123.

Sue Garton, Kathleen Graves. (2014). Materials in ELT: Current Issues. International Perspectives on Materials in ELT, 1-15. 
Sugiono, P. D. (2010). Memahami Penelitian Kualitatif. Bandung: Alfabeta.

Tamo, D. (2009). the use of authentic materials in classrooms. LCPJ. vol2 /1, p

74-78 Tomlinson, B. (2008). English Language Learning Materials. London:

Continuum International $\mathrm{P}$ u b $\mathrm{l}$ i s $\mathrm{h}$ i $\mathrm{n}$ g Group.

Tomlinson, B. (2011). Materials Development in Language Teaching. Cambridge:

Cambridge University Press.

Woodford, K., \& Jackson, G. (2003). Cambridge Advanced Learner's Dictionary.

Cambridge. 